\title{
Effect of intraoperative dexmedetomidine infusion during functional endoscopic sinus surgery: a prospective cohort study
}

\author{
Mohammad Reza Fazel ${ }^{1}$, Zeynab Sadat Ahmadi ${ }^{2}$, Hossein Akbari ${ }^{1}$ and Fahimeh Abam ${ }^{1,2,3^{*}}$
}

\begin{abstract}
Background: Dexmedetomidine, an a2 agonist, has well-known anesthetic and analgesic-sparing effects. We designed this study to evaluate the effect of intraoperative dexmedetomidine infusion on intra operative blood loss and postoperative pain in functional endoscopic sinus surgery.

Methods: This prospective cohort study included 90 patients planning to undergo endoscopic sinus surgery, who were randomly divided into three groups. 2 to $2.5 \mathrm{mg} / \mathrm{kg}$ of propofol was used in all groups to induce anesthesia. One group received dexmedetomidine $0.2 \mu \mathrm{g} / \mathrm{kg}$ per hour infusion whereas the other group received dexmedetomidine $0.5 \mu \mathrm{g} / \mathrm{kg}$ per hour infusion. The control group received normal saline infusion.

Results: The mean age of patients was $41.02 \pm 11.93 .33$ patients in the dexmedetomidine $0.2 \mu \mathrm{g} / \mathrm{kg} / \mathrm{h}$ group, 30 patients in the dexmedetomidine $0.5 \mu \mathrm{g} / \mathrm{kg} / \mathrm{h}$ group and 27 patients in the placebo group. The lowest amount of bleeding was related to the dexmedetomidine $0.5 \mathrm{\mu g} / \mathrm{kg} / \mathrm{h}$ group. The volume of bleeding between the three groups was significantly different $(p=0.012$ ). The satisfaction of the surgeon in the dexmedetomidine $0.5 \mu \mathrm{g} / \mathrm{kg} / \mathrm{h}$ group was more than other groups. There was a significant relationship between the satisfaction of the surgeon and the treatment groups $(p<0.001)$. The lowest duration of surgery was related to the dexmedetomidine $0.2 \mu \mathrm{g} / \mathrm{kg} / \mathrm{h}$ group. The most Trinitroglycerin (TNG) consumption was in the placebo group and the highest dose of labetalol was in the dexmedetomidine $0.5 \mu \mathrm{g} / \mathrm{kg} / \mathrm{h}$ group. There was no significant difference in the TNG and labetalol consumption between three groups. The lowest consumption of morphine and pethidine in the dexmedetomidine $0.5 \mu \mathrm{g} / \mathrm{kg} / \mathrm{h}$ group.
\end{abstract}

Conclusions: Infusion of dexmedetomidine $0.5 \mu \mathrm{g} / \mathrm{kg} / \mathrm{h}$ decreased blood loss and consumption of morphine and pethidine in patients who underwent endoscopic sinus surgery.

Keywords: Dexmedetomidine, Functional endoscopic sinus surgery, Pain, Blood loss

\section{Background}

Rhinostenosis is an inflammatory process of the paranasal sinuses, which is diagnosed based on clinical manifestations, endoscopic findings, and changes in computed tomography (CT) scans [1].. The best treatment is

\footnotetext{
* Correspondence: fahimehabam98@gmail.com

'Department of Radiology, Faculty of Medicine, Kashan University of Medical Sciences, Kashan, Iran

${ }^{2}$ Research Center of Biochemistry and Nutrition in Metabolic Disorder, Kashan University of Medical Sciences, Kashan, Iran

Full list of author information is available at the end of the article
}

endoscopic sinus surgery [2]. Bleeding is one of the most common problems during the sinus endoscopy. Chronic rupture disrupts the field of surgery and increases the risk of problems such as damage to the skull and eye cavity. Hemorrhage increases the duration of surgery due to several interruptions during surgery for suction and compression [3]. Postoperative bleeding also causes delay in discharge of the patient from the hospital [4]. Today, various techniques for reducing intra operative blood loss and the desirability of surgical field are used,

C C The Author(s). 2020 Open Access This article is licensed under a Creative Commons Attribution 4.0 International License, which permits use, sharing, adaptation, distribution and reproduction in any medium or format, as long as you give appropriate credit to the original author(s) and the source, provide a link to the Creative Commons licence, and indicate if changes were made. The images or other third party material in this article are included in the article's Creative Commons licence, unless indicated otherwise in a credit line to the material. If material is not included in the article's Creative Commons licence and your intended use is not permitted by statutory regulation or exceeds the permitted use, you will need to obtain permission directly from the copyright holder. To view a copy of this licence, visit http://creativecommons.org/licenses/by/4.0/ The Creative Commons Public Domain Dedication waiver (http://creativecommons.org/publicdomain/zero/1.0/) applies to the data made available in this article, unless otherwise stated in a credit line to the data. 
Table 1 Mean and standard deviation of volume of hemorrhage and hemoglobin at arrival in the studied groups

\begin{tabular}{llll}
\hline Variable & $\begin{array}{l}\text { Dexmedetomidine } \\
\mathbf{0 . 2} \boldsymbol{\mu g} / \mathbf{k g} / \mathbf{h}\end{array}$ & $\begin{array}{l}\text { Dexmedetomidine } \\
\mathbf{0 . 5} \boldsymbol{\mu g} / \mathbf{k g} / \mathbf{h}\end{array}$ & Placebo \\
\hline Hemorrhage volume $(\mathbf{m l})$ & $252.7 \pm 115$ & $238.3 \pm 87.7$ & $312.9 \pm 83.9$ \\
Initial Hemoglobin(g/d) & $13.90 \pm 1.66$ & $14.33 \pm 1.70$ & $13.94 \pm 1.23$ \\
\hline
\end{tabular}

*ANOVA, $P$-values $<0.05$ were considered statistically significant

which include: 1. Using an intravenous anesthetic method instead of anesthesia with inhalable gases, which has been identified in several studies that this method effectively reduces bleeding and improving the surgical procedure $[5,6]$. 2. Use of local vasoconstrictor drugs, such as adrenaline [7], which is effective in reducing intra operative blood loss. 3Use of anti-fibrinolytic drugs such as tranexamic acid. In several studies, it has been used as an additive [8], topical [8] and intravenous [9] for endoscopic sinus surgery, which has been effective in reducing bleeding and improving the field of surgery in all three methods. 4-Using deliberated hypotension with various drugs including trinitroglycerin and captopril [10] sodium nitroprusside [7] alpha-2 adrenergic agonists such as clonidine, dexmedetomidine, [4] which have been studied in this study to reduce bleeding and improve surgical operations. The above methods can have potential complications. Vascular contraceptive drugs may cause hemodynamic instability, especially in patients with a history of hypertension or ischemic heart disease [9]. Also, inhalation anesthetics cause delay in recovery [4]. And Sodium nitroprusside also causes tachyphylaxis and cyanide poisoning [4]. Recently, alpha-2 agonists have been used to control hemodynamics during surgery and have used them for analgesia in many surgeries. Dexmedetomidine is a highly specific and potent agonist of alpha-2 receptors that has analgesic, antinociceptive and anti-anesthetic properties, as well as sympathetic properties, which simultaneously does not result in respiratory suppression [4]. The central and peripheral sympathetic activity of dexmedetomidine, which is carried out by $\alpha 2$-adrenergic receptors, reduces arterial blood pressure and heart rate and releases norepinephrine dose-dependent. Considering the better effects of dexmedetomidine on hemodynamic control than Clonidine [11, 12], we decided to study the effect of dexmedetomidine on the volume of bleeding and the severity of postoperative pain in endoscopic sinus surgery.

\section{Methods}

Current study is a prospective cohort study in ASA class I and II patients aged 15-75 years old and hemoglobin higher than $10 \mathrm{mg} / \mathrm{dL}$ who referred to Matini Hospital in Kashan, with pansinusitis undergoing endoscopic surgery of the nasal sinus, were studied in 2017.

Patients were examined by the otolaryngologist at the clinic and diagnosed with chronic sinusitis based on clinical observations and CT scan findings. After obtaining written consent, patients were randomly assigned to three groups using a randomized block table [13-17]. Patients in the first group received dexmedetomidine infusion at a dose of $2 . \mu \mathrm{g} / \mathrm{kg}$ Patients in the second group received dexmedetomidine infusion at a dose of $0.5 . \mu \mathrm{g} / \mathrm{kg}$ patients in the third group receive normal saline as a placebo. All surgical procedures were performed by a surgeon who did not have any information on the drug used by the patient. Also, the person who controlled the patient during surgery was unaware of the type of medication. On the day of surgery, patients underwent pulse oximeter monitoring, non-invasive blood pressure measurement, and a coronary artery electrocardiogram. An intravenous route was established for them. The patients received $10 \mathrm{ml} / \mathrm{kg}$ Ringer. Premedication was performed with midazolam $0.03 \mathrm{mg} / \mathrm{kg}$ and $2 \mathrm{mg} / \mathrm{kg}$ Fentanyl. Anesthesia induction was performed by propofol $2 \mathrm{mg} / \mathrm{kg}$ and used to ease intraperitoneal intubation of $0.5 \mathrm{mg} / \mathrm{kg}$ atracurium.

Patients with intubate tube size were fitted with age and sex, and infusion of propofol $100 \mu \mathrm{g} / \mathrm{kg} / \mathrm{min}$ with $50 \% \mathrm{~N}_{2} \mathrm{O}$ and oxygen was used to continue anesthesia. During the operation, fentanyl $1 \mu \mathrm{g} / \mathrm{kg}$ and atracurium $0.15 \mathrm{mg} / \mathrm{kg}$ every $45 \mathrm{~min}$ were repeated. Mechanical ventilation was the same for all patients with a flow volume of $10 \mathrm{ml} / \mathrm{kg}$, respiratory rate of 10 times per minute. At the end of the procedure, all patients with Atropine $30 \mu \mathrm{g} / \mathrm{kg}$ and Neostigmine $60 \mu \mathrm{g} / \mathrm{kg}$ were reversed.

Table 2 Mean and standard deviation of pain intensity in the studied groups at different times

\begin{tabular}{|c|c|c|c|c|c|c|}
\hline Time & $\begin{array}{l}\text { Dexmedetomidine } \\
0.2 \mu \mathrm{g} / \mathrm{kg} / \mathrm{h} \\
(n=33)\end{array}$ & $\begin{array}{l}\text { Dexmedetomidine } \\
0.5 \mu \mathrm{g} / \mathrm{kg} / \mathrm{h} \\
(n=30)\end{array}$ & $\begin{array}{l}\text { Placebo } \\
(n=27)\end{array}$ & *P & $* * P$ & $* * * \mathrm{P}$ \\
\hline $2 \mathrm{~h}$ after surgery & $2.66 \pm 1.67$ & $2.13 \pm 1.45$ & $4.77 \pm 1.16$ & $>0.001$ & $>0.001$ & 0.013 \\
\hline $6 \mathrm{~h}$ after surgery & $3.18 \pm 1.62$ & $2.23 \pm 1.47$ & $4.44 \pm 1.64$ & $>0.001$ & & \\
\hline $12 \mathrm{~h}$ after surgery & $2.54 \pm 1.60$ & $1.70 \pm 1.41$ & $3.40 \pm 1.47$ & $>0.001$ & & \\
\hline $24 \mathrm{~h}$ after surgery & $1.96 \pm 1.26$ & $1.33 \pm 1.15$ & $2.59 \pm 1.24$ & $>0.001$ & & \\
\hline
\end{tabular}

*ANOVA ** time effect*** time groups effect. $P$-values $<0.05$ were considered statistically significant 
Table 3 Mean and standard deviation of systolic blood pressure in the studied groups at different times

\begin{tabular}{|c|c|c|c|c|c|c|}
\hline Time & $\begin{array}{l}\text { Dexmedetomidine } \\
0.2 \mu \mathrm{g} / \mathrm{kg} / \mathrm{h} \\
(n=33)\end{array}$ & $\begin{array}{l}\text { Dexmedetomidine } \\
0.5 \mu \mathrm{g} / \mathrm{kg} / \mathrm{h} \\
(n=30)\end{array}$ & $\begin{array}{l}\text { Placebo } \\
(n=27)\end{array}$ & *P & $* * P$ & $* * * P$ \\
\hline Before induction & $125.39 \pm 18.23$ & $129.50 \pm 13.21$ & $126.29 \pm 20.59$ & 0.630 & \multirow[t]{4}{*}{$>0.001$} & \multirow[t]{4}{*}{0.024} \\
\hline After induction & $125.84 \pm 17.32$ & $124.63 \pm 15.03$ & $122.14 \pm 19.70$ & 0.710 & & \\
\hline End of surgery & $110.48 \pm 16.74$ & $113.43 \pm 15.73$ & $105.48 \pm 9.62$ & 0.124 & & \\
\hline Recovery state & $111.27 \pm 13.24$ & $109.26 \pm 10.97$ & $118.25 \pm 12.52$ & 0.019 & & \\
\hline
\end{tabular}

* ANOVA ** time effect ${ }^{* * *}$ time groups effect. $P$-values $<0.05$ were considered statistically significant

Systolic and diastolic blood pressure, heart rate, and saturated oxygen before and after induction, after intubation during surgery, were recorded every 15 min until the end of surgery. In the course of operation, if the field of bleeding was greater than Grade 3 (Table 1), to improve the surgical status of patients infusion of Trinitroglycerin (TNG) $(0.25-0.5 \mathrm{~g} / \mathrm{kg} / \mathrm{min})$ was started to reduce the mean arterial pressure (MAP) less than 80 $\mathrm{mmHg}$. In patients whose blood pressure was not controlled by TNG or tachycardia, labetalol was used at doses of $5 \mathrm{mg}$. The amount of bleeding was calculated based on the lost volume and pharyngeal weight estimation. After the surgery and extubation, the patient was transferred to recovery. The patient was kept in recovery for $2 \mathrm{~h}$. Demographic data of patients including sex, height and weight were recorded in a pre-designed questionnaire. Also, the length of surgery and anesthesia, hemoglobin before and $12 \mathrm{~h}$ after operation, the amount of TNG consumed, the amount of bleeding during operation and up to $12 \mathrm{~h}$ after surgery, the surgeon's satisfaction with the operation was also noted.

\section{Statistical analysis}

Initially, the normalization of the dependent variables is investigated using Kolmogorov Smirnov test [18-20], then, if the data are normal, binary variations in each group are performed using paired $\mathrm{t}$-test and comparison of the two groups is done using independent t-test [2127]. Also, Wilcoxon rank-sum test and Mann-Whitney $\mathrm{U}$ test were used to analyze abnormal data. Finally, analysis of variance with repeated measurements was used to analyze the changes of related factors over time. $P$ - values $<0.05$ were considered statistically significant [28-31]. All statistical analyses were done using the Statistical Package for Social Science version 19 (SPSS Inc., Chicago, Illinois, USA) [32-34].

\section{Results}

In this study, 90 patients were studied. The mean age of patients was $41.02 \pm 11.93 .33$ patients in the dexmedetomidine group $0.2 \mu \mathrm{g} / \mathrm{kg} / \mathrm{h}, 30$ patients in the dexmedetomidine group received $0.5 \mu \mathrm{g} / \mathrm{kg} / \mathrm{hr}$. and 27 patients in the placebo group. Sexual abnormalities did not differ significantly between the three groups.

In Table 1, based on the results, the lowest volume of hemorrhage associated with the dexmedetomidine group is $0.5 \mu \mathrm{g} / \mathrm{kg} / \mathrm{h}$. The volume of bleeding was significantly different between the three groups $(p=0.122)$. The LSD post hoc test showed a significant difference between the control and the other two groups, while the difference between the two concentrations of dexmedetomidine was not observed $(p<0.05)$. Hemoglobin was not significantly different between the three groups at baseline $(p=0.50)$.

Also, the results showed that the satisfaction of the surgeon in the dexmedetomidine group was $0.5 \% \mu \mathrm{g} / \mathrm{kg} /$ $\mathrm{h}$ more than other groups and there was a significant relationship between the satisfaction of the surgeon and the treatment groups $(p<0.001)$.

As shown in Table 2, the lowest pain levels at 2, 6, 12 and $24 \mathrm{~h}$ after surgery were related to the dexmedetomidine group $0.5 \mu \mathrm{g} / \mathrm{kg} / \mathrm{h}$. The analysis of variance with repeated measurements showed the effect of time on pain intensity changes, which indicates changes in pain

Table 4 Mean and standard deviation of diastolic blood pressure in the studied groups at different times

\begin{tabular}{|c|c|c|c|c|c|c|}
\hline Time & $\begin{array}{l}\text { Dexmedetomidine } \\
0.2 \mu \mathrm{g} / \mathrm{kg} / \mathrm{h} \\
(n=33)\end{array}$ & $\begin{array}{l}\text { Dexmedetomidine } \\
0.5 \mu \mathrm{g} / \mathrm{kg} / \mathrm{h} \\
(n=30)\end{array}$ & $\begin{array}{l}\text { Placebo } \\
(n=27)\end{array}$ & *P & $* * \mathrm{P}$ & $* * * \mathrm{P}$ \\
\hline Before induction & $77.24 \pm 9.75$ & $82.60 \pm 8.85$ & $76.74 \pm 8.40$ & 0.026 & $>0.001$ & 0.013 \\
\hline After induction & $78.36 \pm 7.92$ & $80.20 \pm 10.01$ & $73.03 \pm 11.46$ & 0.020 & & \\
\hline End of surgery & $72.18 \pm 12.31$ & $74.96 \pm 12.34$ & $68.74 \pm 11.27$ & 0.155 & & \\
\hline Recovery state & $70.15 \pm 10.10$ & $70.40 \pm 12.37$ & $75.18 \pm 9.76$ & 0.148 & & \\
\hline
\end{tabular}

*ANOVA ** time effect*** time groups effect. $P$-values $<0.05$ were considered statistically significant 
Table 5 Duration of operation, and the amount used drugs for reducing blood pressure in the studied groups at different times

\begin{tabular}{|c|c|c|c|c|}
\hline Time & $\begin{array}{l}\text { Dexmedetomidine } \\
0.2 \mu \mathrm{g} / \mathrm{kg} / \mathrm{h} \\
(n=33)\end{array}$ & $\begin{array}{l}\text { Dexmedetomidine } \\
0.5 \mu \mathrm{g} / \mathrm{kg} / \mathrm{h} \\
(n=30)\end{array}$ & $\begin{array}{l}\text { Placebo } \\
(n=27)\end{array}$ & $p$-value* \\
\hline Surgery duration (min) & $74.54 \pm 13.99$ & $79.83 \pm 21.99$ & $85.55 \pm 13.03$ & 0.047 \\
\hline TNG & $2.01 \pm 2.50$ & $1.98 \pm 2.24$ & $2.24 \pm 1.88$ & 0.896 \\
\hline Labetalol & $11.96 \pm 8.47$ & $15.16 \pm 11.02$ & $13.14 \pm 8.45$ & 0.401 \\
\hline
\end{tabular}

*ANOVA. $P$-values $<0.05$ were considered statistically significant

intensity in the three studied groups during the measurement times $(P<0.001)$. Also, the interactive effect of time and therapeutic groups on pain changes revealed the difference between treatment groups over time on pain changes $(P=0.013)$.

Also, according to the results, the lowest heart rate before induction, after induction and end of operation with dexmedetomidine group was $0.5 \mu \mathrm{g} / \mathrm{kg} / \mathrm{h}$, but in the recovery phase it was $0.2 \mu \mathrm{g} / \mathrm{kg} / \mathrm{h}$. Analysis of variance with repeated measurements revealed the effect of time factor on heart rate changes, which indicates changes in heart rate in the three studied groups during measurement times $(P<0.001)$. Also, there was no interaction between time factor and therapeutic groups on changes in heart rate, which indicates that there is no difference between treatment groups over time on changes in heart $\operatorname{rate}(P=.392)$.

In Table 3, based on the results, the lowest systolic blood pressure before the induction was related to the 0.2 dexmedetomidine group, after the induction and the end of operation was related to the placebo group, and in the recovery state the dexmedetomidine group was 0.5 . Analysis of variance with repeated measurements revealed the effect of time factor on systolic blood pressure changes, indicating changes in systolic blood pressure in the three studied groups over time $(P<0.001)$. The effect of time agent and therapeutic groups on the changes in systolic blood pressure was also seen, indicating the difference between treatment groups over time on systolic blood pressure changes $(P=0.024)$.

In Table 4, the least amount of diastolic blood pressure was observed before and after the induction and the end of the operation in the placebo group. In the recovery, the lowest pressure was related to 0.2 dexmedetomidine. Analysis of variance with repeated measurements revealed the effect of time factor on diastolic blood pressure changes, which indicates diastolic blood pressure changes in the three groups studied during the measurement times $(P<$ 0.001 ). Also, the interaction effect of time agent and therapeutic groups on diastolic blood pressure changes, which indicates the difference between treatment groups over time on diastolic blood pressure changes $(P=0.013)$.

Based on the results, the highest percentage of arterial oxygen saturation (SPO2) before and after recovery was related to the placebo group. After induction was related to 0.5 dexmedetomidine group and at the end of operation the dexmedetomidine group was 0.2 . Analysis of variance with repeated measurements showed the effect of time factor on $\mathrm{SPO} 2$ variations, which indicates that $\mathrm{SPO} 2$ changes were not observed in the three study groups during the measurement times $(P=0.386)$. Also, the interaction effect of time agent and treatment groups on $\mathrm{SPO} 2$ changes was observed, indicating no difference between treatment groups over time on SPO2 changes $(P=0.523)$.

In Table 5, the duration of the operation and the amount of blood pressure reducing drugs used in the studied groups at different times are presented. The lowest duration of action was related to the $0.2 \mathrm{dex}$ medetomidine group. LSD post hoc test showed a significant difference between the control and the other two groups. However, this difference was not observed between the two concentrations of dexmedetomidine $(p<0.05)$. The highest TNG consumption was in the placebo group and the highest dose of Labetalol was in the 0.5 dexmedetomidine group. There was no significant difference in TNG and Labetalol in the three groups $(P=0.401)$.

In Table 6, the mean and standard deviation of drug consumption in the studied groups are presented at different times. As it can be seen, the lowest levels of morphine and pethidine used were related to the 0.5 dexmedmotidine group.

Table 6 Mean and standard deviation of drug consumption in the studied groups at different times

\begin{tabular}{lllll}
\hline Time & $\begin{array}{l}\text { Dexmedetomidine } \\
\mathbf{0 . 2} \boldsymbol{\mu g} / \mathbf{k g} / \mathbf{h} \\
(\boldsymbol{n}=\mathbf{3 3})\end{array}$ & $\begin{array}{l}\text { Dexmedetomidine } \\
\mathbf{0 . 5} \boldsymbol{\mu g} / \mathbf{k g} / \mathbf{h} \\
(\boldsymbol{n}=\mathbf{3 0 )}\end{array}$ & $\begin{array}{l}\text { Placebo } \\
(\boldsymbol{n}=\mathbf{2 7})\end{array}$ \\
\hline Morphine (mg) & $1.24 \pm 1.75$ & $1.00 \pm 1.25$ & $1.62 \pm 2.27$ & $\boldsymbol{p}$-value* \\
Pethidine (mg) & $9.51 \pm 11.00$ & $3.00 \pm 7.02$ & $14.88 \pm 10.77$ & $>0.414$ \\
\hline
\end{tabular}

*ANOVA. $P$-values $<0.05$ were considered statistically significant 


\section{Discussion}

Overall, 90 consecutive patients were enrolled in this study.to determine the effect of dexmedetomidine on the volume of bleeding and the severity of postoperative pain in endoscopic sinus surgery. The mean age of patients was $41.02 \pm 11.93$ years. 33 patients in the dexmedetomidine group $0.2 \mu \mathrm{g} / \mathrm{kg} / \mathrm{h}, 30$ patients in the dexmedetomidine group received $0.5 \mu \mathrm{g} / \mathrm{kg} / \mathrm{h}$ and $27 \mathrm{pa}-$ tients in the placebo group. The lowest amount of bleeding in the dexmedetomidine group was $0.5 \mu \mathrm{g} / \mathrm{kg} / \mathrm{h}$. The volume of bleeding between the three groups was significantly different $(p=0.122)$. The satisfaction of the surgeon in the dexmedmotidine group was $0.5 \% \mu \mathrm{g} / \mathrm{kg} / \mathrm{h}$ more than other groups. The satisfaction of the surgeon was significantly correlated with the treatment groups $(p<0.001)$. The lowest pain levels at 2,6,12 and $24 \mathrm{~h}$ after surgery were related to the dexmedmotidine group $0.5 \mu \mathrm{g} / \mathrm{kg} / \mathrm{h}$. The lowest duration of action was related to the dexmedmotidine group $0.2 \mu \mathrm{g} / \mathrm{kg} / \mathrm{h}$. The LSD post hoc test showed a significant difference between the control and the other two groups, while the difference between the two concentrations of dexmedmotidine was not observed $(p<0.05)$. The highest TNG consumption was in the placebo group and the highest dose of Labetalol was $0.5 \mu \mathrm{g} /$ $\mathrm{kg} / \mathrm{h}$ in dexmedmotidine group.

In a study done by Anjan Das comparing the effect of dexmedmotidine and clonidine on controlled hypotension and postoperative endoscopic sinus surgery was shown that dexmedmotidine had a greater effect on the control of pressure and decreased bleeding during surgery and postoperative pain [11], which these findings were similar to those of our study.

In another study, the effect of dexmedmotidine versus Esmolol on controlled hypotension in endoscopic sinus surgery was investigated, which showed that dexmedmotidine was more effective [4]. In our study, the dexmedmotidine group in contrast to the placebo group also had more efficacy on controlling pressure and reducing bleeding during surgery and postoperative pain. The study by Alex Becker and colleagues found that the effects of dexmedmotidine and propofol doses compared to fentanyl and propofol on the quality of recovery and postoperative fatigue in patients undergoing spinal surgery revealed that recovery was better in dexmedmotidine-propofol group as well as patients had fewer postoperative symptoms [35], which is an indication of our study results. In another study, comparing the effect of dexmedmotidine versus placebo on recovery quality in $24 \mathrm{~h}$ after surgery, and its effect on postoperative vomiting, showed that single dose of dexmedmotidine improved recovery quality and decreased vomiting in recovery unit [36]. In our study, the group receiving dexmedmotidine had less relief in recovery compared to placebo. A study by Ramamani Mariappan. compared the effect of oral clonidine versus dexmedmotidine on the amount of need for anesthetic during surgery and the quality of recovery and hemodynamic control in spinal surgery, which showed that hemodynamic control and recovery quality in each two groups were equal and the amount of anesthetic was higher in the dexmedmotidine group [37]. In our study, the duration of the operation and the result of the anesthetic level in the dexmedmotidine group were less than $0.2 \mu \mathrm{g} / \mathrm{kg} / \mathrm{h}$ of the other groups.

In another study, dexmedmotidine was compared with placebo on early postoperative cognitive impairment in postoperative laparoscopic cholecystectomy in elder people, which showed that dexmedmotidine significantly reduced postoperative early cognitive impairment in the elderly laparoscopic cholecystectomy surgery [38]. Other research group also examined the need for postoperative sedation drugs in the group of dexmedmotidine and total intravenous anesthesia (TIVA) versus Remifentanil and TIVA in Genomic Laparoscopic Video Surgery, indicating that the need for Postoperative analgesics for postoperative pain decreased in the dexmedmotidine and TIVA groups [39], which was similar to our study result. In another study, comparing the effect of dexmedmotidine+Desflurane and placebo+Desflurane on the amount of post-operative need of sedation drugs and postoperative vomiting and survival in the recovery unit in Laparoscopic bariatric surgery showed that the issues were decreased in the dexmedmotidine+Desflurane group, [40] which was similar to the result of our study.

\section{Conclusion}

The lowest volume of bleeding related to the dexmedmotidine group was $0.5 \mu \mathrm{g} / \mathrm{kg} / \mathrm{h}$. The lowest pain levels in the 2,6,12 and $24 \mathrm{~h}$ postoperative pain group were $0.5 \mu \mathrm{g} / \mathrm{kg} / \mathrm{hr}$. dexmedmotidine. The lowest duration of action was related to the 0.2 dexmedmotidine group and the lowest levels of morphine and pethidine used were in the 0.5 dexmedmotidine group. Consequently, the current results realize that the infusion of dexmedetomidine reduces blood loss and consumption of morphine and pethidine in patients undergoing endoscopic sinus surgery.

\section{Acknowledgements \\ The researcher wishes to express his appreciation to the full cooperation of the patients who participated in this study.}

\section{Authors' contributions}

All the authors participated in the study design. MRF, ZA, HA and FA collected and documented the data and assisted in preliminary data analysis. FA and MRF wrote the initial draft. FA and MRF participated in draft revision, data analysis and editing of the final draft. The author(s) read and approved the final manuscript.

\section{Funding}

The financial support for the current research was provided by Research Deputy of Kashan University of Medical Sciences, Kashan, Iran. 


\section{Availability of data and materials}

The dataset used in this study is available with the authors and can be made available upon request.

\section{Ethics approval and consent to participate}

All procedures performed in studies involving human participants were in accordance with the ethical standards of the institutional and national research committee and with the 1964 Helsinki declaration and its later amendments.

\section{Consent for publication}

Not applicable.

\section{Competing interests}

The authors declared that they have no competing interests.

\section{Author details}

'Department of Radiology, Faculty of Medicine, Kashan University of Medical Sciences, Kashan, Iran. ${ }^{2}$ Research Center of Biochemistry and Nutrition in Metabolic Disorder, Kashan University of Medical Sciences, Kashan, Iran. ${ }^{3}$ Department of Community Medicine, School of Medicine, Social Determinants of Health Research Center, Kashan University of Medical Sciences, Kashan, Iran.

Received: 4 March 2020 Accepted: 29 September 2020

Published online: 13 October 2020

\section{References}

1. Cheng Y, Xue F, Wang TY, et al. Analyses and treatments of postoperative nasal complications after endonasal transsphenoidal resection of pituitary neoplasms. Medicine (Baltimore). 2017;96(15):e6614. https://doi.org/10.1097/ MD.0000000000006614.

2. Iwasaki T, Saitoh I, Takemoto Y, Inada E, Kanomi R, Hayasaki H, Yamasaki Y. Improvement of nasal airway ventilation after rapid maxillary expansion evaluated with computational fluid dynamics. Am J Orthod Dentofac Orthop. 2012:141(3):269-78.

3. Flint PW, Haughey BH, Niparko JK, Richardson MA, Lund VJ, Robbins KT, Lesperance MM, Thomas JR. Cummings otolaryngology-head and neck surgery E-book: head and neck surgery, 3-volume set: Elsevier health sciences; 2010.

4. Guven DG, Demiraran Y, Sezen G, Kepek O, Iskender A. Evaluation of outcomes in patients given dexmedetomidine in functional endoscopic sinus surgery. Ann Otol Rhinol Laryngol. 2011;120(9):586-92.

5. Wormald PJ, Van Renen G, Perks J, Jones JA, Langton-Hewer CD. The effect of the total intravenous anesthesia compared with inhalational anesthesia on the surgical field during endoscopic sinus surgery. Am J Rhinol. 2005; 19(5):514-20.

6. Ankichetty SP, Ponniah M, Cherian V, Thomas S, Kumar K, Jeslin L, Jeyasheela K, Malhotra N. Comparison of total intravenous anesthesia using propofol and inhalational anesthesia using isoflurane for controlled hypotension in functional endoscopic sinus surgery. J Anaesthesiol Clin Pharmacol. 2011;27(3):328.

7. Panda N, Verma RK, Panda NK. Efficacy and safety of high-concentration adrenaline wicks during functional endoscopic sinus surgery. J Otolaryngol Head Neck Surg. 2012;41(2):131-7. https://doi.org/10.2310/7070.2011.110177.

8. Yaniv E, Shvero J, Hadar T. Hemostatic effect of tranexamic acid in elective nasal surgery. Am J Rhinol. 2006;20(2):227-9.

9. Alimian M, Mohseni $M$. The effect of intravenous tranexamic acid on blood loss and surgical field quality during endoscopic sinus surgery: a placebocontrolled clinical trial. J Clin Anesth. 2011;23(8):611-5.

10. Činčikas D, Ivaškevičius J. Application of controlled arterial hypotension in endoscopic rhinosurgery. Medicina. 2003;39(9):852-9.

11. Das A, Mukherje A, Chhaule S, Chattopadhyay S, Halder P, Mitra T, Basunia S, Mandal S. Induced hypotension in ambulatory functional endoscopic sinus surgery: A comparison between dexmedetomidine and clonidine as premedication. A prospective, double-blind, and randomized study. Saudi J Anaesth. 2016:10(1):74

12. Mizrak A, Karatas E, Saruhan R, Kara F, Oner U, Saricicek V, Baysal E. Does dexmedetomidine affect intraoperative blood loss and clotting tests in pediatric adenotonsillectomy patients? J Surg Res. 2013;179(1):94-8.
13. Alavi NM, Madani M, Sadat Z, Kashani HH, Sharif MR. Fatigue and vitamin D status in Iranian female nurses. Global J Health Sci. 2016:8(6):196.

14. Sharif MR, Kheirkhah D, Madani M, Kashani HH. The relationship between iron deficiency and febrile convulsion: a case-control study. Global J Health Sci. 2016;8(2):185.

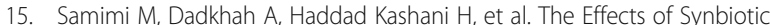
Supplementation on Metabolic Status in Women With Polycystic Ovary Syndrome: a Randomized Double-Blind Clinical Trial. Probiotics \& Antimicro. Prot. 2019;11:1355-61. https://doi.org/10.1007/s12602-018-9405-z.

16. Haddad Kashani H, Seyed Hosseini E, Nikzad H, Soleimani A, Soleimani M, Tamadon MR, Keneshlou F, Asemi Z. The effects of vitamin D supplementation on signaling pathway of inflammation and oxidative stress in diabetic hemodialysis: a randomized, double-blind, placebo-controlled trial. Front Pharmacol. 2018;9:50

17. Saba MA, Valeh $T$, Ehteram H, Kashani HH, Zahedi MG. Diagnostic value of neuron-specific enolase (NSE) and cancer antigen 15-3 (CA 15-3) in the diagnosis of pleural effusions. Asian Pac J Cancer Prev. 2017;18(1):257.

18. Ferdosian M, Khatami MR, Malekshahi ZV, Mohammadi A, Kashani HH, Shooshtari MB. Identification of immunotopes against Mycobacterium leprae as immune targets using PhDTm-12mer phage display peptide library. Trop J Pharm Res. 2015;14(7):1153-9.

19. Sharif MR, Kashani HH, Ardakani AT, Kheirkhah D, Tabatabaei F, Sharif A. The effect of a yeast probiotic on acute diarrhea in children. Probiotics Antimicrob Proteins. 2016;8(4):211-4

20. Kashani HH, Nikzad H, Mobaseri S, Hoseini ES. Synergism effect of nisin peptide in reducing chemical preservatives in food industry. Life Sci J. 2012;9(1):496-501.

21. Sharif A, Kashani HH, Nasri E, et al. The Role of Probiotics in the Treatment of Dysentery: a Randomized Double-Blind Clinical Trial. Probiotics \& Antimicro. Prot. 2017;9:380-5. https://doi.org/10.1007/s12602-017-9271-0.

22. Piroozmand A, Kashani HH, Zamani B. Correlation between Epstein-Barr virus infection and disease activity of systemic lupus erythematosus: a crosssectional study. Asian Pac J Cancer Prev. 2017;18(2):523.

23. Tamadon MR, Soleimani A, Keneshlou F, Mojarrad MZ, Bahmani F, Naseri A, Kashani HH, Hosseini ES, Asemi Z. Clinical trial on the effects of vitamin D supplementation on metabolic profiles in diabetic hemodialysis. Horm Metab Res. 2018:50(01):50-5.

24. Moghaddasi Mohammad S, Kashani HH, Azarbad Z. Capparis spinosa L. Propagation and medicinal uses. Life Sci J. 2012;9(4):684-6.

25. Kashani HH, Moniri R. Expression of recombinant pET22b-LysK-cysteine/ histidine-dependent amidohydrolase/peptidase bacteriophage therapeutic protein in Escherichia coli BL21 (DE3). Osong Public Health Res Perspect. 2015;6(4):256-60.

26. Kashani HH, Moshkdanian G, Atlasi MA, Taherian AA, Naderian H, Nikzad H. Expression of galectin-3 as a testis inflammatory marker in vasectomised mice. Cell J. 2013;15(1):11.

27. Najaran H, Rashtbari H, Mohammadi A, Soleimanifar F, Izadpanah F, Kashani $\mathrm{HH}$, Bafrani $\mathrm{HH}$. The protective effect of coenzyme Q10 and berberine on sperm parameters, with and without varicocelectomy in rats with surgically induced varicoceles. Comp Clin Pathol. 2019;28(2):479-85.

28. Kamani M, Hosseini ES, Kashani HH, Atlasi MA, Nikzad H. Protective Effect of Lepidium sativum Seed Extract on Histopathology and Morphology of Epididymis in Diabetic Rat Model. Int J Morphol. 2017;35(2).

29. Razavi M, Jamilian M, Samimi M, Ebrahimi FA, Taghizadeh M, Bekhradi R, Hosseini ES, Kashani HH, Karamali M, Asemi Z. The effects of vitamin D and omega-3 fatty acids co-supplementation on biomarkers of inflammation, oxidative stress and pregnancy outcomes in patients with gestational diabetes. J Nutr Metab. 2017:14(1):80.

30. Mazoochi T, Khamechian T, Ehteram M, Kashani HH. The effect of melatonin on expression of p53 and ovarian preantral follicle development isolated from vitrified ovary. Comp Clin Pathol. 2018;27(1):83-8.

31. Hosseini ES, Zarei MA, Babashah S, Sistani RN, Sadeghizadeh M, Kashani HH, Mahabadi JA, Izadpanah F, Atlasi MA, Nikzad H. Studies on combination of oxaliplatin and dendrosomal nanocurcumin on proliferation, apoptosis induction, and long non-coding RNA expression in ovarian cancer cells. Cell Biol Toxicol. 2019;35(3):247-66.

32. Lotfi $A$, Shiasi $K$, Amini $R$, Jahangiri $M$, Sharif MR, Akbari $H$, Talari $H$, Hajmobini Z, Hami K, Kashani HH. Comparing the effects of two feeding methods on metabolic bone disease in newborns with very low birth weights. Global J Health Sci. 2016;8(1):249.

33. Jalali HK, Salamatzadeh A, Jalali AK, Kashani HH, Asbchin SA, Issazadeh K Antagonistic activity of Nocardia brasiliensis PTCC 1422 against isolated 
Enterobacteriaceae from urinary tract infections. Probiotics Antimicrob Proteins. 2016;8(1):41-5.

34. Haddad Kashani H, Fahimi H, Dasteh Goli Y, Moniri R. A novel chimeric endolysin with antibacterial activity against methicillin-resistant Staphylococcus aureus. Front Cell Infect Microbiol. 2017;7:290.

35. Bekker A, Haile M, Kline R, Didehvar S, Babu R, Martiniuk F, Urban M. The effect of intraoperative infusion of dexmedetomidine on quality of recovery after major spinal surgery. J Neurosurg Anesthesiol. 2013;25(1):16.

36. Kim S, Oh Y, Park B, Sim J, Choi Y. Effects of single-dose dexmedetomidine on the quality of recovery after modified radical mastectomy: a randomised controlled trial. Minerva Anestesiol. 2013;79(11):1248-58.

37. Mariappan R, Ashokkumar H, Kuppuswamy B. Comparing the effects of oral clonidine premedication with intraoperative dexmedetomidine infusion on anesthetic requirement and recovery from anesthesia in patients undergoing major spine surgery. J Neurosurg Anesthesiol. 2014;26(3):192-7.

38. Li Y, He R, Chen S, Qu Y. Effect of dexmedetomidine on early postoperative cognitive dysfunction and peri-operative inflammation in elderly patients undergoing laparoscopic cholecystectomy. Exp Ther Med. 2015;10(5):1635-42.

39. Bulow NMH, Barbosa NV, Rocha JBT. Opioid consumption in total intravenous anesthesia is reduced with dexmedetomidine: a comparative study with remifentanil in gynecologic videolaparoscopic surgery. I Clin Anesth. 2007:19(4):280-5.

40. Tufanogullari B, White PF, Peixoto MP, Kianpour D, Lacour T, Griffin J, Skrivanek G, Macaluso A, Shah M, Provost DA. Dexmedetomidine infusion during laparoscopic bariatric surgery: the effect on recovery outcome variables. Anesth Analg. 2008;106(6):1741-8.

\section{Publisher's Note}

Springer Nature remains neutral with regard to jurisdictional claims in published maps and institutional affiliations.

Ready to submit your research? Choose BMC and benefit from:

- fast, convenient online submission

- thorough peer review by experienced researchers in your field

- rapid publication on acceptance

- support for research data, including large and complex data types

- gold Open Access which fosters wider collaboration and increased citations

- maximum visibility for your research: over $100 \mathrm{M}$ website views per year

At $\mathrm{BMC}$, research is always in progress.

Learn more biomedcentral.com/submissions 